\title{
ESTIMASI DEBIT LIMPASAN MENGGUNAKAN METODE NATURAL RESOURCES CONSERVATION SOIL (NRCS) UNTUK OPTIMALISASI TUTUPAN LAHAN DI DAS SERANG DAERAH ISTIMEWA YOGYAKARTA
}

\author{
Iwuk Sri Lestari ${ }^{1}$, Totok Gunawan ${ }^{2}$, dan Slamet Suprayogi ${ }^{3}$
}

BPDAS Serayu, Opak, Progo ${ }^{1}$, Fakultas Geografi, Universitas Gadjah Mada ${ }^{2,3}$, Yogyakarta, Indonesia iwuksl@gmail.com

Diterima : Desember 2015; Direvisi : Juni 2016; Dipubikasikan: September 2016

\begin{abstract}
ABSTRAK Ada banyak faktor yang menyebabkan kondisi DAS menjadi kritis. Perubahan tutupan lahan menjadi salah satu pemicu awal terjadinya kondisi kritis tersebut. Terlebih dengan makin bertambahnya jumlah penduduk, menyebabkan pemanfaatan sumber daya alam makin meningkat. Perubahan tutupan lahan pun akan makin banyak terjadi. Perubahan tutupan lahan yang intensif ke arah tutupan lahan yang tidak bervegetasi menyebabkan limpasan (overlandflow) meningkat. Pada pengelolaan DAS, limpasan (overlandflow) ini penting untuk diperhatikan, karena merupakan komponen penting penyumbang air ke saluran yang menggambarkan dampak perubahan tutupan lahan yag terjadi. Dengan diketahui perubahan tutupan lahan dan limpasan yang dihasilkan, maka dapat disusun suatu skenario tutupan lahan agar limpasan yang dihasilkan terkendali. Penelitian ini bertujuan untuk: 1) Mempelajari sebaran nilai CN-lereng di DAS Serang; 2) Mengkaji besarnya limpasan yang dihasilkan dengan menggunakan nilai CN dan CN-lereng; 3) Menyusun skenario optimalisasi tutupan lahan untuk mengendalikan besarnya limpasan. Metode yang digunakan dalam penelitian ini adalah Natural Resources Conservation Soil (NRCS) dengan penyesuaian (memasukkan) lereng. Penyesuaian lereng digunakan untuk mengetahui pengaruh lereng pada nilai CN. Hasil penyesuaian lereng pada nilai CN disebut $\mathrm{CN}$-lereng. CN-lereng ini kemudian digunakan untuk mengestimasi tebal limpasan dan digunakan untuk menyusun skenario tutupan lahan. Estimasi limpasan di DAS Serang menggunakan data hujan harian. Peta Tanah, Peta Tutupan Lahan, dan Peta Lereng dibuat menggunakan Sistem Informasi Geografi (SIG). Hasil penelitian menunjukkan 1) Nilai CN-lereng lebih tinggi dari nilai CN; 2) Limpasan dengan menggunakan nilai CN-lereng lebih tinggi dibanding dengan nilai CN. Ini membuktikan bahwa lereng berpengaruh pada limpasan yang dihasilkan; 3) Limpasan dapat dikendalikan dengan skenario tutupan lahan yang telah disusun dengan mengubah cara pengolahan lahan dan tutupan lahannya.
\end{abstract}

Kata kunci: Curve Number (CN); Curve Number-Lereng (CN-Lereng); penyesuaian lereng; skenario tutupan lahan.

ABSTRACT There are many factors that causes the watershed being critical. Changes in land cover into one trigger the onset of the critical condition. Especially with the growing number of the population, causing the utilization of natural resources is increasing. Changes in land cover will be more and more the case. Intensive land cover change to un vegetated land cover cause overlandflow increasing. On watershed management, overlandflow is important to note, because it is an important component contributing to water channels that describe the impact of land cover changes which occurred. With the known changes in land cover and the runoff is generated, it can be arranged a land cover scenarios so that the resulting overlandflow control. The objcetives of this research are: 1) to study the spatial distribution CN-slope values in Serang Watershed; 2) to study overlandflow which estimate using CN and CN-slope values; 3) to arrange land cover scenario for controlling overlandflow. The methode applied in this research is Natural Resources Conservation Soil(NRCS) with slope adjustment.Slope adjustment used to know effect of slope on CN values. Result of slope adjustment called as CN-Slope values The CN-Slope valaues were followed to estimate overlandflow depth and used to arranged the land cover scenario.Estimated the overlandflow in Serang Watershed used daily rainfall. Soil map, Land Cover map and Slope map were generated in Geographical Information System (GIS). The result showed that 1) the CN-Slope values are higher than CN values; 2) Overlandflow using CN-Slope values are higher than overlandflow using CN value. It gives proof that slope influence on overlandflow depth; 3) Overlandflow can be control by land cover scenarios arranged with to change land management and land cover.

Key words: Curve Number; Curve Number-Slope; slope adjusment; scenario land cover.

\section{PENDAHULUAN}

Menurut Keputusan Menteri Kehutanan No.328/Menhut-II/2009 tentang Penetapan Urutan DAS Prioritas, saat ini terdapat 108 DAS yang berada dalam kondisi kritis. Perubahan tutupan lahan dapat menjadi salah satu pemicu awal terjadinya kondisi kritis tersebut. Terlebih dengan makin bertambahnya jumlah penduduk, pemanfaatan sumber daya alam akan semakin intensif. Perubahan tutupan lahan pun akan makin banyak terjadi.

Perubahan tutupan lahan yang intensif kearah tutupan lahan yang tidak bervegetasi menyebabkan limpasan (overlandflow) meningkat. Air hujan yang jatuh tidak dapat masuk ke dalam tanah. Air tersebut kemudian terakumulasi dan mengisi cekungancekungan tanah. Jika air berlebih, maka air tersebut 
menjadi limpasan (overlandflow). Limpasan (overlandflow) ini merupakan pergerakan air yang masih ada di lahan atau sebelum mencapai saluran. Pada pengelolaan DAS, limpasan (overlandflow) ini penting untuk diperhatikan, karena merupakan komponen penting penyumbang air ke saluran (Sudarmadji dkk., 2014). Limpasan (overlandflow) merupakan pemicu awal (trigger) terbentuknya aliran pada saluran (surface runoff atau stream channel). Oleh karena itu merupakan hal pertama yang harus mendapat perhatian, kaitannya dengan perubahan tutupan lahan yang terjadi. Besarnya limpasan ini dapat diestimasi dengan menggunakan metode Natural Resources Conservation Soil (NRCS) (Sudarmadji dkk.. 2014). Secara umum metode ini sangat responsif terhadap besarnya limpasan yang dihasilkan di dalam DAS (Ponce and Hawkins, 1996). Metode ini sangat cocok untuk menggambarkan dan memprediksi limpasan kaitannya dengan perubahan tutupan lahan. Metode ini juga dapat digunakan untuk mengestimasi limpasan pada DAS yang tidak memiliki Stasiun Pengamat Aliran Sungai (SPAS) (Ponce and Hawkins, 1996).

Berdasarkan latar belakang diatas, maka untuk mengetahui besarnya limpasan akibat perubahan tutupan lahan pada DAS yang tidak memiliki Stasiun Pengamat Aliran Sungai (SPAS) dapat dilakukan dengan menggunakan metode NRCS. Mengingat metode ini berlaku untuk daerah dengan rata-rata kemiringan lereng $<30 \%$, maka nilai $\mathrm{CN}$ dipandang perlu disesuaikan terlebih dahulu untuk kemiringan lereng $>30 \%$ yang ada di daerah penelitian.

Berkaitan dengan hal tersebut, maka dirumuskan tujuan penelitian sebagai berikut:

1. Mengkaji sebaran spasial nilai CN-lereng di DAS Serang

2. Mengkaji besarnya limpasan DAS Serang, baik limpasan yang diperoleh dengan menggunakan nilai $\mathrm{CN}$ dan $\mathrm{CN}$-Lereng

3. Menyusun skenario optimalisasi tutupan lahan di DAS Serang untuk mengendalikan besarnya limpasan.

\section{METODE PENELITIAN}

Penelitian dilakukan di DAS Serang dilakukan pada bulan Desember hingga Juni 2015. Secara geografis DAS Serang terletak pada 395.442,076 mT-411.604,89 $\mathrm{mT}$ dan 9.145.163,088 mU-9.119.968,212 mU.
Peralatan yang digunakan dalam penelitian ini meliputi GPS, kantong plastik, sekop, meteran, spidol, kamera, alat tulis, komputer dan printer. Software yang digunakan adalah Arc GIS 9.x, dan microsoft office. Bahan yang digunakan meliputi Peta RBI skala 1:25.000, Peta Tanah, Peta Lereng, Peta Tutupan Lahan, Digital Elevation Model (DEM), SPOT 5 dan Google Earth.

Metode estimasi limpasan yang digunakan dalam penelitian ini adalah metode Natural Resources Conservation Soil (NRCS). Metode ini dapat digunakan untuk mengestimasi volume limpasan pada DAS yang tidak memiliki stasiun duga air (Ponce and Hawkins, 1996). Menurut Asdak (2002) metode ini berlaku untuk daerah dengan rata-rata kemiringan lereng kurang dari 30\%. Sehingga untuk daerah dengan kemiringan lereng yang bervariasi, maka perlu dilakukan penyesuaian nilai $\mathrm{CN}$ untuk berbagai kemiringan lereng tersebut (Williams, 1995 dalam Neitsch et al., 2011).

Satuan lahan merupakan unit analisis yang digunakan dalam penelitian ini. Satuan lahan disusun berdasarkan peta bentuk lahan, tutupan lahan dan tanah. Pada satu satuan lahan yang sama ini, kondisi fisik dan hidrologinya juga sama, sehingga sampel yang diambil pada satu satuan lahan ini dinggap mewakili satuan lahan yang ada. Pengambilan sampel tanah untuk menguji tekstur tanah dan sampel infiltrasi untuk mengukur kapasitas infiltrasi lapangan dilakukan pada setiap satuan lahan yang dominan.

Sebaran Spasial Nilai CN-Lereng di DAS Serang, dilakukan dengan terlebih dahulu menentukan tutupan lahan, Kelompok Hidrologi Tanah (KHT) (Tabel 1 dan 2), nilai Curve Number (CN) (Tabel 3 dan 4), dan nilai CN-Lereng. Penentuan tutupan lahan dilakukan melalui citra SPOT 5 dan Google Earth selanjutnya dilakukan ceking lapangan. KHT ditentukan berdasarkan nilai infiltrasi tanah (Tabel 1) dikombinasikan dengan tekstur tanah (Tabel 2).

Tabel 1. Klasifikasi Laju Infiltrasi

\begin{tabular}{clc}
\hline Kelas & Laju Infiltrasi & Besarnya Infiltrasi $(\mathrm{mm} /$ jam $)$ \\
\hline 0 & Sangat Lambat & $<2,5$ \\
I & Lambat & $2,5-15$ \\
II & Sedang & $15-28$ \\
III & Tinggi & $28-53$ \\
IV & Sangat Tinggi & $>53$ \\
\hline
\end{tabular}

Sumber: ILRI (1974) dalam Gunawan (1991) 
Tabel 2. Klasifikasi Infiltrasi Berdasarkan Tekstur Tanah

\begin{tabular}{cll}
\hline Kelompok Hidrologi Tanah & \multicolumn{1}{c}{ Keterangan } & \multicolumn{1}{c}{ Tekstur } \\
\hline A & Infiltrasi tinggi, runoff rendah & $\begin{array}{l}\text { Pasir (sand), Pasir bergeluh (loamy sand), Geluh berpasir } \\
\text { (sandy loam) }\end{array}$ \\
B & Infiltrasi sedang, runoff sedang & $\begin{array}{l}\text { Geluh berdebu (silty loam), Geluh (loam) } \\
\text { C }\end{array}$ \\
Infiltrasi lambat, runoff sedang-tinggi & Geluh lempung berpasir (sandy clay loam) \\
& Infiltrasi sangat lambat, runoff tinggi & $\begin{array}{l}\text { Geluh berlempung (clay loam), Geluh lempung berdebu } \\
\text { (silty clay loam), Lempung berpasir (sandy clay), Lempung }\end{array}$ \\
& & berdebu (silty clay), Lempung (clay) \\
\hline
\end{tabular}

Sumber: Schroder

Nilai CN diperoleh melalui tumpang susun antara tutupan lahan dan KHT. Penentuan nilai CN-Lereng dengan memasukkan faktor lereng menggunakan persamaan NRCS, 2009 sebagai berikut:

$\mathrm{CN}_{2}$ lereng $=\mathrm{CN}_{2} \times \mathrm{K}$

$\boldsymbol{K}=$

$(322,79+(15,56 x \alpha))$ $(\alpha+323,52)$

dimana: $\mathrm{CN}_{2}$ adalah nilai $\mathrm{CN}$ standar dalam kondisi normal (ARC II), K adalah konstanta, dan $\alpha$ adalah lereng (persen).

Estimasi limpasan total per sub DAS nilai $\mathrm{CN}_{2}$ merupakan $\mathrm{CN}$ tertimbang sub DAS dengan besar lereng (\%) tertimbang sub DAS, dengan persamaan berikut:

Lereng tertimbang $=\sum a_{i} x s_{i} / \mathrm{A}$

dimana $\alpha_{\mathrm{i}}$ adalah luas lereng $(\mathrm{km})$; $\mathrm{s}_{\mathrm{i}}$ adalah lereng (\%) dan A adalah luas poligon.

Besarnya limpasan DAS Serang diperoleh melalui persamaan:

$Q=\frac{(P-0,2 S)^{2}}{(P+0,8 S)} \quad$ jika $P>I a ;$ dan $Q=0$ jika $P \leq I a$

Sumber : NRCS (2004)

dimana $\mathrm{Q}=$ tebal limpasan $(\mathrm{mm}) ; \mathrm{P}=$ curah hujan harian $(\mathrm{mm}) ; \quad \mathrm{Ia}=$ initial abstraction termasuk simpanan permukaan, intersepsi dan evaporasi ( $\mathrm{mm})$; $\mathrm{S}=$ retensi potensial maksimum setelah limpasan mulai atau curah hujan pada DAS saat aliran dimulai ( $\mathrm{mm})$. S mencerminkan tanah dan kondisi tutupan lahan di dalam DAS yang diperoleh melalui sebuah kurva (Curve Number/CN). Nilai CN antara 0 hingga 100 dan nilai $\mathrm{S}$ berhubungan dengan $\mathrm{CN}$ sebagai berikut:

$S=\frac{25400}{C N}-254$

dimana 25400 dan 254 adalah tetapan

Nilai CN sendiri akan berubah-ubah sesuai dengan kelembaban yang didasarkan pada total hujan 5 hari terakhir. Kondisi kelembaban berdasarkan total hujan 5 hari terakhir tersebut disebut Antecendent Runoff Condition (ARC). Kondisi ARC I (kering) jika total hujan 5 hari terakhir $<35 \mathrm{~mm}$. Kondisi ARC II (normal) jika total hujan 5 hari terakhir 35-52,5 mm. Kondisi ARC III (basah) jika total hujan 5 hari terakhir $>52,5 \mathrm{~mm}$. Perubahan nilai CN pada berbagai kondisi kelembaban dapat diperoleh melalui persamaan berikut (NRCS, 2004):

$C N_{I}=4,2 C N_{I I} /\left(10-0,058 C N_{I I}\right)$

$C N_{I I I}=23 C N_{I I} /\left(10+0,13 C N_{I I}\right)$.

dimana nilai $\mathrm{CN}_{\mathrm{II}}$ adalah nilai $\mathrm{CN}$ yang diperoleh dari Lampiran 1 dan 2.

DAS dengan banyak tutupan lahan dapat menggunakan komposit curve number dalam analisisnya (NRCS, 2004). Hal yang perlu dicatat disini adalah ketika komposit curve number digunakan, analisis tidak memperhitungkan lokasi tutupan lahan tertentu, tetapi melihat area DAS sebagai tutupan lahan seragam diwakili dengan nilai komposit curve number. Persamaan yang digunakan untuk menghitung komposit curve number sebagai berikut (NRCS, 2004):

$C N_{a w}=\frac{\sum_{i=1}^{n}\left(C N_{i} \times A_{i}\right)}{\sum_{i=1}^{n} A_{i}}$

dimana: $\mathrm{CN}_{\mathrm{aw}}=$ nilai $\mathrm{CN}$ tertimbang untuk seluruh DAS/sub DAS; $\mathrm{CN}_{\mathrm{i}}=$ nilai $\mathrm{CN}$ untuk setiap poligon hasil tumpang susun dari penutupan lahan dan kelompok hidrologi tanah; $A_{i}=$ luas setiap poligon hasil tumpang susun dari penutupan lahan dan kelompok hidrologi tanah; $\mathrm{n}=$ jumlah setiap poligon penutupan lahan-kelompok hidrologi tanah di DAS/sub DAS.

Besarnya tebal limpasan dengan menggunakan $\mathrm{CN}$ atau CN-Lereng adalah dengan memasukkan data hujan harian $(\mathrm{P})$, dan retensi potensial maksimum (S) dengan nilai $\mathrm{CN}$ atau $\mathrm{CN}$-Lereng pada persamaan (4). Tebal limpasan ini diestimasi pada kondisi ARC I, II, dan III. Setelah tebal limpasan diperoleh, volume limpasan dihitung dengan mengalikan tebal limpasan $\left(\mathrm{Q}_{\mathrm{mm}}\right)$ dengan luas DAS. Sementara besarnya debit diperoleh dengan membagi volume limpasan dengan waktu (detik) selama 24 jam.

Skenario optimalisasi tutupan lahan disusun dengan cara melakukan uji coba terhadap rencana tutupan lahan hingga diperoleh besar limpasan paling kecil dan koefisien limpasan minimal 0,5. Besarnya 
limpasan ini menjadi variabel utama dalam optimalisasi tutupan lahan. Namun demikian tetap mempertimbangkan aspek sosial, ekonomi, teknis dan kebijakan yang ada. Keempat aspek sosial tersebut akan dianalisis secara deskripsi untuk mendapatkan suatu kondisi yang optimal menurut masyarakat.

\section{HASIL DAN PEMBAHASAN}

\section{Hujan Harian Sebagai Input}

Data hujan yang digunakan untuk mengestimasi besarnya tebal limpasan $\left(\mathrm{Q}_{\mathrm{mm}}\right)$ adalah data hujan harian Tahun 2014 yang jatuh merata di semua stasiun. Stasiun yang digunakan sebanyak 12 stasiun hujan yang ada di DAS Serang dan sekitarnya. Dua belas stasiun tersebut antara lain stasiun Kaligesing, Singkung, Kenteng, Plaosan, Gembongan, Boroarea, Kokap, Pengasih, Wates, Panjatan, Hargorejo, dan Temon. Estimasi tebal limpasan dilakukan pada 11 kejadian hujan dari bulan Januari hingga Desember tahun 2014. Besarya hujan dihitung menggunakan metode polygon thiessen. Selain hujan harian sebagai input, besarnya akumulasi hujan 5 hari terakhir digunakan untuk menentukan kondisi ARC (Antecendent Runoff Condition). Kondisi ARC ini perlu diketahui untuk menentukan nilai Curve Number (CN) yang digunakan.

\section{Sebaran Nilai Curve Number (CN)}

Sebaran nilai $\mathrm{CN}$ di lokasi penelitian ditunjukkan pada Gambar 2. Nilai $\mathrm{CN}$ paling dominan merupakan tutupan hutan-kombinasi rumput (kebun buah dan pohon) dengan kondisi baik pada kelompok tanah B. Meliputi lahan seluas $90,57 \mathrm{~km}^{2}(42,79 \%)$. Nilai CN sebesar 58 (pada kondisi ARC II). Nilai CN dominan kedua berupa tegalan dengan tutupan unggul atau sebaran kacang-kacangan atau padang rumput pada kelompok tanah $\mathrm{C}$ dengan penanaman jalur lurus. Meliputi lahan seluas $21,25 \mathrm{~km}^{2}(10,04 \%)$. Nilai CN sebesar 81 (pada kondisi ARC II). Nilai CN 81 diprediksi memiliki tebal limpasan yang lebih besar dibanding lahan dengan nilai 58. Sebab makin tinggi nilai $\mathrm{CN}$, maka tebal limpasan juga semakin besar. Dengan kata lain tegalan dengan tutupan unggul/sebaran kacang-kacangan/padang rumput dalam kondisi buruk dengan pengolahan jalur lurus akan memiliki tebal limpasan yang lebih besar dibanding kebun dengan tutupan hutan-kombinasi rumput (kebun buah dan pohon) dalam kondisi baik.

Lahan dengan sebaran nilai $\mathrm{CN}$ tinggi paling (ditandai dengan warna merah pada Gambar 2) banyak berada di sub DAS Sumitro, sedikit di sub DAS Sekiyep, dan dibagian hilir sub DAS Sidatan, Nagung dan Serang Hilir. Umumnya berpenutup lahan tegalan, sawah tadah hujan dan sawah irigasi. Lahan dengan nilai CN rendah (warna hijau pada Gambar 2) paling banyak ditemukan di sub DAS Ngrancah, sub DAS Nagung dan sebagian kecil di sub DAS Sumitro, sub DAS Sidatan dan sub DAS Serang Hilir. Umumnya berpenutup lahan kebun (hutan-kombinasi rumput, kebun buah dan pohon).

\section{Tebal Limpasan dengan Menggunakan Nilai Curve Number (QCN)}

Tebal limpasan diestimasi untuk masing-masing sub DAS. Curah hujan yang digunakan sebagai input adalah hujan harian yang jatuh merata di seluruh DAS. Estimasi tebal limpasan ini dilakukan dengan asumsi mengabaikan besarnya intersepsi, simpanan air pada permukaan, simpanan air pada saluran, waktu tempuh limpasan dari hulu ke hilir DAS/sub DAS, suhu, kelembaban, dan intensitas hujan. Tebal limpasan yang dimaksud adalah tebal limpasan yang dihasilkan pada lahan disetiap sub DAS dengan tutupan lahan dan tanah yang berbeda.

Pada uji coba dengan hujan wilayah masing-masing sub DAS sebagai input. Pada kondisi ARC dan nilai CN yang sama, semakin tinggi curah hujan semakin besar tebal limpasan yang dihasilkan. Pada tanggal 11 Desember dengan hujan lebih tinggi $(42,85 \mathrm{~mm})$ menghasilkan tebal limpasan yang lebih besar $(14,73$ $\mathrm{mm}$ ) dengan debit sebesar 9,64 $\mathrm{m}^{3} /$ detik. Sementara pada tanggal 22 Desember dengan hujan lebih rendah $(16,82 \mathrm{~mm})$ menghasilkan tebal limpasan yang lebih kecil $(1,21 \mathrm{~mm})$ dengan debit sebesar $0,79 \mathrm{~m}^{3} /$ detik.

Semakin tinggi ARC dan $\mathrm{CN}$, dengan hujan yang makin tinggi, tebal limpasan yang dihasilkan juga semakin tinggi. Sebaliknya semakin rendah ARC, CN makin rendah, dengan hujan makin rendah, tebal limpasan juga makin rendah. Sebagai contoh tebal limpasan di sub DAS Serang Hilir pada tanggal 17 November lebih tinggi (13,89 $\mathrm{mm}$ dengan debit sebesar $6,5 \mathrm{~m}^{3} /$ detik) dibanding tebal limpasan pada tanggal 11 Desember 2014 (0,61 mm). Pada tanggal 17 November kondisinya lebih basah (ARC III), dibanding tanggal 11 Desember (kondisi normal/ARC II). Nilai CN tanggal 17 November juga lebih tinggi (86) dibanding nilai CN tanggal 11 Desember (73). Oleh karena pada tanggal 17 November kondisinya memang lebih basah/jenuh, ditambah hujan yang lebih tinggi, menyebabkan tanah makin jenuh. Pada kondisi demikian air hujan yang jatuh tidak mampu terinfiltrasi lagi, sehingga volume limpasan yang dihasilkan lebih besar dibanding tanggal 11 Desember.

Tebal limpasan akan tetap tinggi pada kondisi ARC dan $\mathrm{CN}$ yang lebih tinggi, meskipun hujan yang jatuh lebih rendah. Sebagai contoh di sub DAS Sumitro. Pada kejadian hujan tanggal 24 Februari $(32,40 \mathrm{~mm})$ dan 13 Maret (41,62 mm). Tebal limpasan tanggal 24 Februari 
$(8,15 \mathrm{~mm})$ tetap lebih tinggi dibanding tanggal 13 Maret $(4,15 \mathrm{~mm})$. Meskipun hujan pada tanggal 13 Maret lebih tinggi. Kondisi demikian dapat terjadi, sebab pada tanggal 24 Februari kondisi tanah lebih basah. Pada kondisi demikian penambahan hujan sedikit saja, akan menghasilkan tebal limpasan yang lebih tinggi. Kondisi tanah yang lebih basah mengurangi kemampuan infiltrasi air, sehingga air yang jatuh sebagian besar akan menjadi limpasan. Kondisi ini berbeda dengan tanggal 13 Maret yang memiliki kondisi kelembaban normal (ARC dan CN lebih rendah). Hujan yang jatuh, meskipun lebih tinggi, sebagian besar akan mampu terinfiltrasi ke dalam tanah, sehingga tebal limpasan pada tanggal 13 Maret tetap lebih kecil.

Sementara itu pada uji coba dengan hujan wilayah seluruh DAS Serang sebagai input. Diketahui bahwa dengan hujan dan ARC yang sama, makin tinggi nilai $\mathrm{CN}$, semakin besar tebal limpasan. Contoh kejadian hujan tanggal 29 November. Hujan yang jatuh merata diseluruh sub DAS sebesar 29,66 mm pada kondisi ARC II. Nilai CN bervariasi antar sub DAS menunjukkan bahwa kondisi tutupan lahan dan tanah yang berbeda antar sub DAS. Makin tinggi nilai CN, menghasilkan tebal limpasan yang semakin tinggi pula. Nilai $\mathrm{CN}$ yang semakin tinggi menandakan bahwa tutupan lahan dan tanah memiliki kemampuan infiltrasi yang rendah, sehingga tebal limpasan meningkat.

Pada kondisi ARC yang sama, dengan hujan dan nilai $\mathrm{CN}$ yang makin tinggi, menghasilkan tebal limpasan yang semakin tinggi. Sebab dengan makin bertambahnya hujan, tanah akan semakin lembab, sehingga kapasitas infiltrasi akan berkurang, dan semakin banyak air hujan menjadi limpasan.

Berdasarkan estimasi yang dilakukan diantara enam sub DAS yang ada di DAS Serang, sub DAS yang memiliki tebal limpasan tertinggi adalah sub DAS Sumitro dan Serang Hilir. Sub DAS Sumitro memiliki tebal limpasan sebesar 16,19 mm dengan debit sebesar $10,55 \mathrm{~m}^{3} /$ detik. Sub DAS Serang Hilir memiliki tebal limpasan sebesar 16,84 $\mathrm{mm}$ dengan debit sebesar 7,83 $\mathrm{m}^{3} /$ detik. Berdasarkan besarnya debit limpasan tersebut dapat dikatakan bahwa penyumbang limpasan terbesar di DAS Serang adalah limpasan yang dihasilkan dari lahan yang ada di sub DAS Sumitro dan sub DAS Serang Hilir. Ini dapat berarti pula bahwa sub DAS yang paling banyak mengalami erosi adalah sub DAS Sumitro dan Serang Hilir. Sebab semakin tinggi limpasan berarti daya angkut dari air semakin tinggi, sehingga peluang bagi tanah untuk hanyut dan terangkut hingga ke hilir semakin tinggi. Pada akhirnya sedimentasi yang terjadi di bagian hilir DAS Serang juga semakin besar.

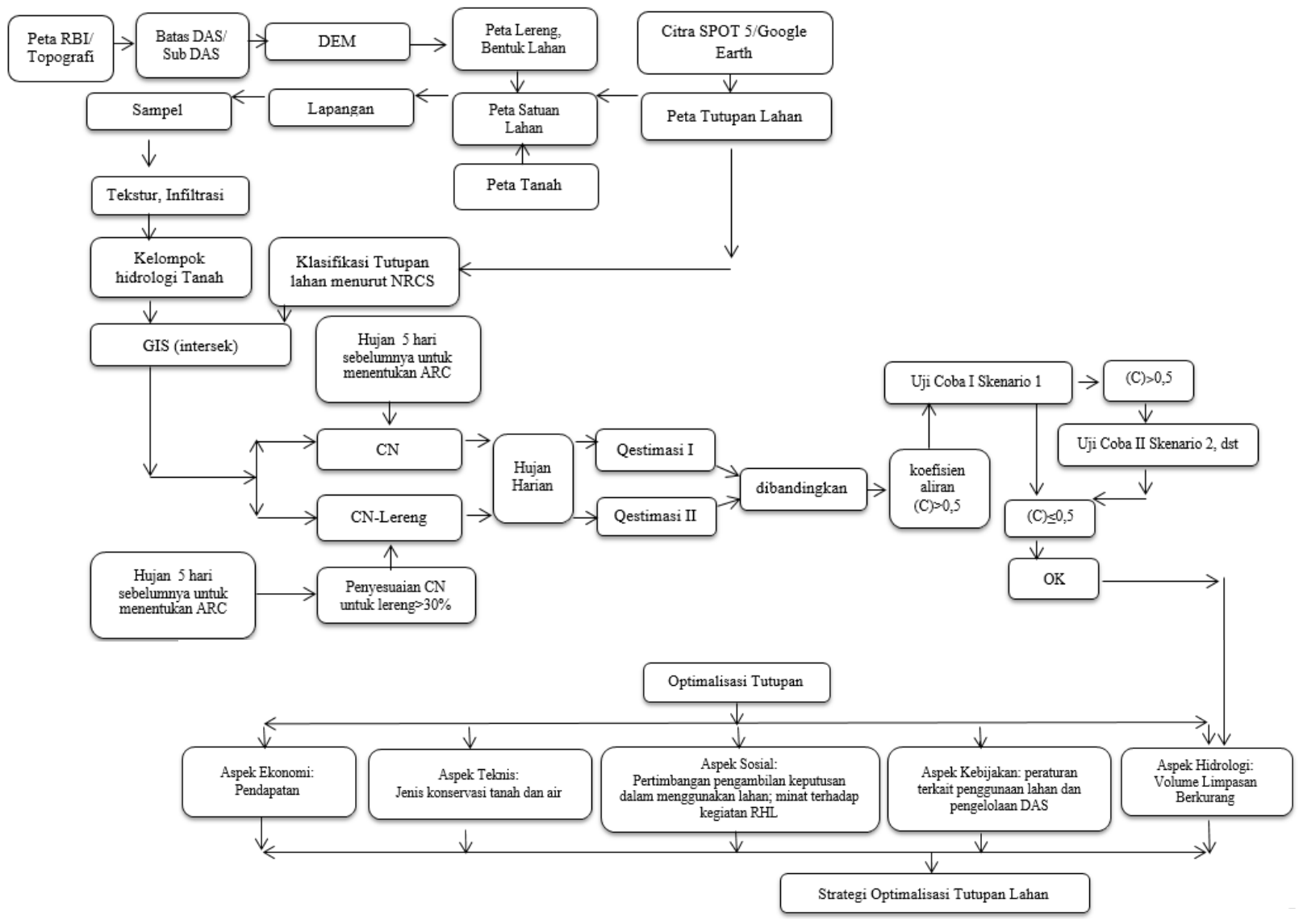

Gambar 1. Diagram Alir Penelitian 


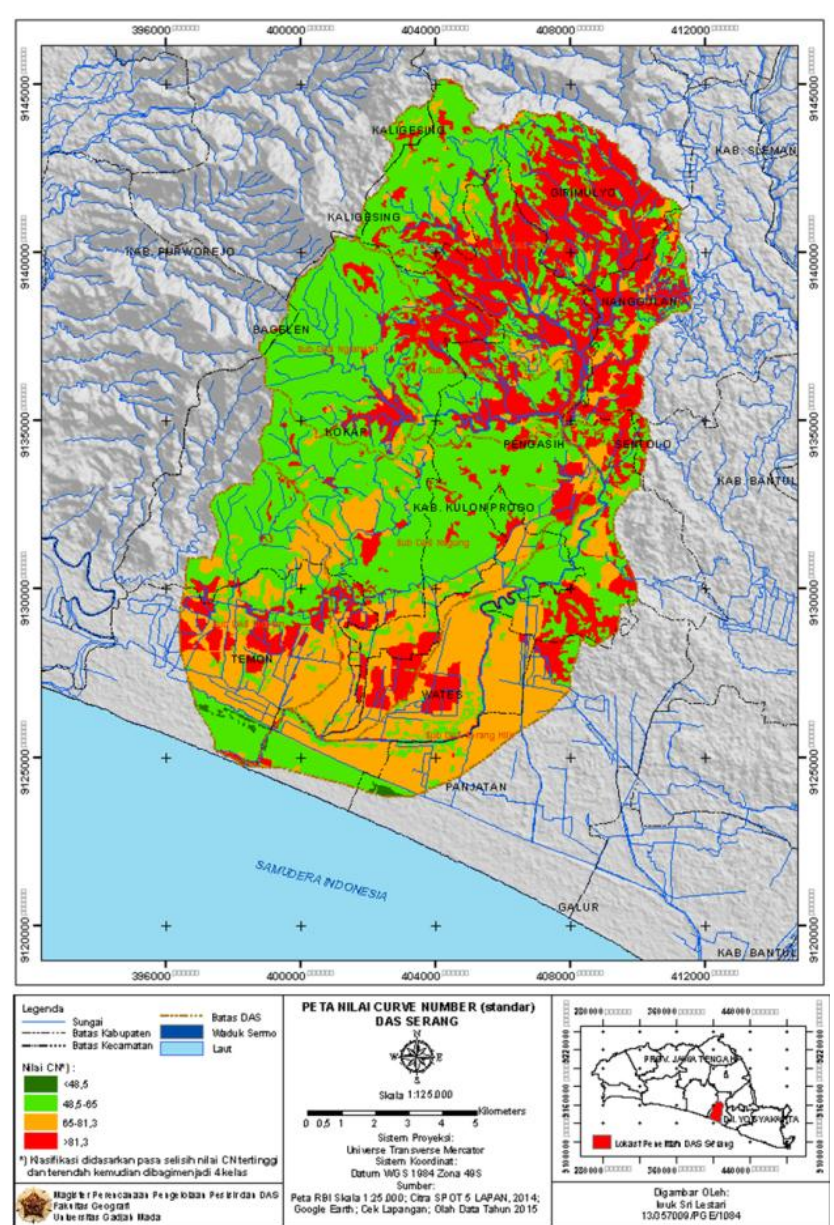

Gambar 2. Peta Sebaran Nilai CN (ARC II) di DAS Serang

\section{Penyesuaian Nilai Curve Number dengan Lereng (CN- Lereng)}

Penyesuaian nilai $\mathrm{CN}$ dilakukan hanya untuk lahan dengan kemiringan lereng $>30 \%$. Penyesuaian ini dilakukan karena menurut Asdak (2002), metode NRCS berlaku untuk DAS dengan rata-rata kemiringan lereng $<30 \%$, sehingga perlu dilakukan penyesuaian nilai CN terhadap lereng (NRCS, 2009). Lereng merupakan salah satu faktor yang turut mempengaruhi besarnya tebal limpasan yang dihasilkan. Penyesuaian nilai $\mathrm{CN}$ terhadap lereng menghasilkan nilai $\mathrm{CN}$ baru yang kemudian disebut dengan CN-lereng. Sebaran nilai CN-Lereng DAS Serang tersaji dalam Gambar 3.

Sub DAS yang memiliki lereng lebih 30\% adalah sub DAS Ngrancah, Sumitro, Sekiyep, Nagung dan Sidatan. Sementara pada Sub DAS Serang Hilir tidak dilakukan penyesuian $\mathrm{CN}$ dengan lereng, sebab sub DAS ini tidak memiliki lahan dengan kemiringan lereng $>30 \%$. Nilai CN-Lereng sedikit lebih tinggi dibanding CN. Sebagaimana telah disebutkan di awal bahwa semakin tinggi nilai $\mathrm{CN}$, tebal limpasan yang dihasilkan akan semakin besar. Sehingga diprediksi estimasi tebal limpasan dengan menggunakan $\mathrm{CN}$ lereng menjadi sedikit lebih besar dibanding estimasi tebal limpasan dengan menggunakan CN. Meskipun hanya berpengaruh sedikit, penelitian ini membuktikan bahwa lereng tetap berpengaruh terhadap tebal limpasan yang dihasilkan di lokasi penelitian. Lokasi penelitian merupakan daerah dengan lereng yang bervariasi, sehingga dipandang perlu memasukkan faktor lereng dalam estimasi tebal limpasannya.

Sebaran nilai CN-Lereng di DAS Serang disajikan dalam Gambar 2. Tampak warna merah yang menandakan nilai $\mathrm{CN}$ lebih tinggi mendominasi lahan di bagian hulu sub DAS Sumitro dan sub DAS Sekiyep. Pada sub DAS Ngrancah, sub DAS Sidatan dan sub DAS Nagung nilai CN-Lereng ditandai dengan warna hijau yang lebih terang di bagian hulu. Sisanya adalah lahan dengan lereng $<30 \%$ sehingga nilai $\mathrm{CN}$ tidak berubah.

\section{Tebal Limpasan dengan Menggunakan Nilai Curve Number-Lereng $\left(Q_{\mathrm{CN} \text {-Lereng }}\right)$}

Hasil estimasi tebal limpasan menggunakan nilai CN-Lereng menghasilkan tebal limpasan yang sedikit lebih tinggi dibanding hasil estimasi menggunakan nilai CN. Hasil ini membenarkan prediksi awal bahwa tebal limpasan dengan menggunakan $\mathrm{CN}$-lereng menjadi sedikit lebih besar dibanding estimasi tebal limpasan dengan menggunakan CN. Selain itu juga membuktikan bahwa lereng turut berpengaruh meningkatkan tebal limpasan. 


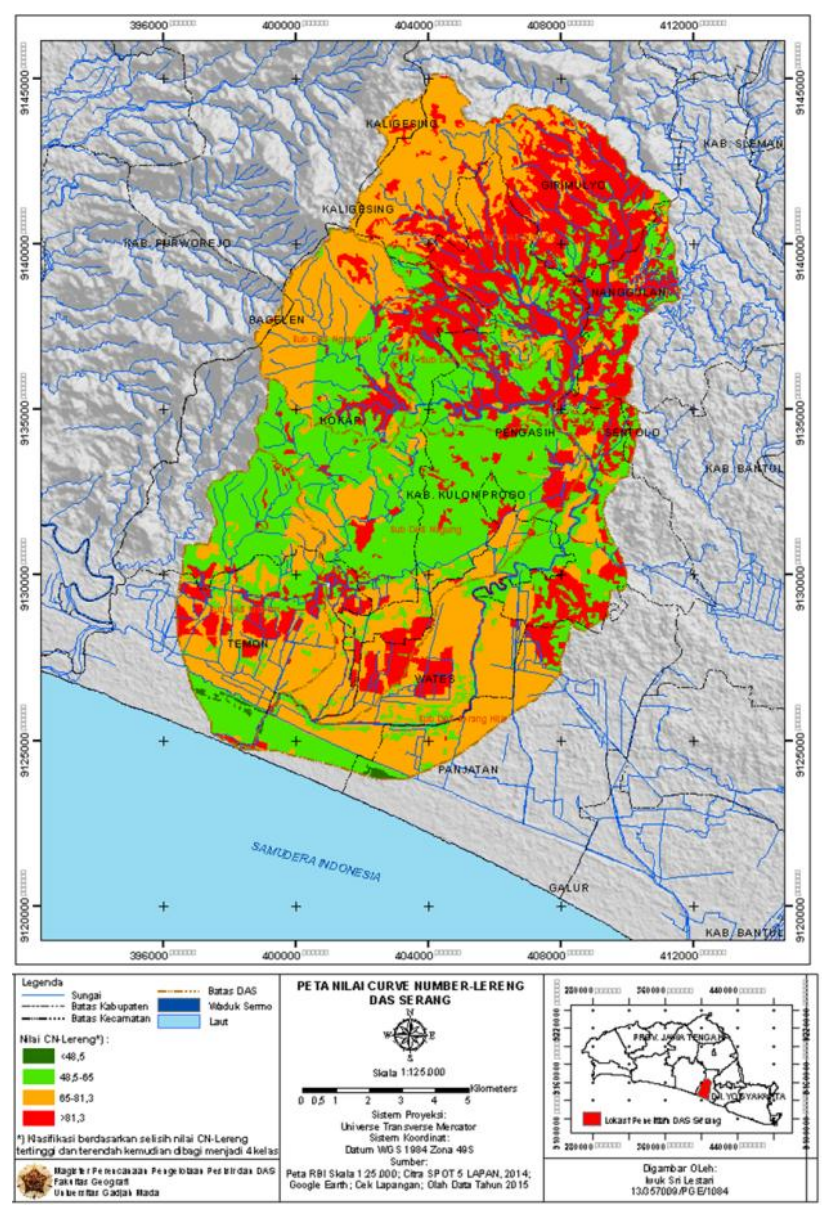

Gambar 3. Peta Sebaran Nilai CN-Lereng (ARC II) di DAS Serang

Secara garis besar hasil estimasi limpasan menggunakan $\mathrm{CN}$-Lereng dan $\mathrm{CN}$ memiliki kesamaan pola. Kesamaan pola tersebut antara lain:

1. Pada kondisi kelembaban (ARC) yang sama, CNLereng sama, makin tinggi hujan, semakin besar tebal limpasan yang dihasilkan. Alasannya semakin banyak hujan yang jatuh, tanah akan semakin basah dan jenuh. Saat tanah menjadi jenuh berarti air tidak dapat terinfiltrasi ke dalam tanah. Kelebihan air inilah yang kemudian mengalir menjadi limpasan.

2. Semakin tinggi kelembaban (ARC) dan nilai $\mathrm{CN}$, dengan hujan makin tinggi, volume limpasan juga makin tinggi. Pada ARC III, kondisi tanah lebih lembab dibanding ARC II dan ARC I. Pada kondisi ini tanah semakin jenuh. Kelebihan air akan mudah menjadi limpasan. Ditambah lagi dengan nilai $\mathrm{CN}$ yang semakin tinggi yang berarti kapasitas infiltrasi tanah makin lambat dengan tutupan lahan yang makin tidak rapat. Sehingga dengan semakin banyak hujan, maka air akan semakin banyak yang tidak terinfiltrasi dan berubah menjadi limpasan.

3. Pada hujan dan ARC yang sama, semakin tinggi nilai CN-Lereng, makin tinggi volume limpasan yang dihasilkan. Sebab makin tinggi nilai $\mathrm{CN}$ lereng berarti kapasitas infiltrasi tanah makin lambat, tutupan lahan makin jarang dengan kondisi perakaran yang tidak membantu terjadinya infiltrasi, ditambah lereng yang semkin miring/curam menyebabkan air limpasan akan dengan cepat terbentuk dan menjadi lebih tinggi.

Hasil estimasi dengan CN-Lereng menunjukkan sub DAS Sumitro dan sub DAS Serang Hilir tetap menjadi penyumbang terbesar limpasan di DAS Serang dibanding sub DAS Sidatan, Sekiyep, Nagung dan Ngrancah (Tabel 3). Dengan asumsi bahwa hasil estimasi yang dilakukan sudah dianggap benar, maka skenario optimalisasi tutupan lahan dapat disusun dalam rangka mengurangi limpasan yang ada di setiap sub DAS.

\section{Skenario Optimalisasi Tutupan Lahan Menggunakan Nilai CN-Lereng}

Optimalisasi tutupan lahan dilakukan dengan maksud untuk mengurangi tebal limpasan yang dihasilkan masing-masing sub DAS. Berdasarkan estimasi tebal limpasan yang telah dilakukan, dari 11 kejadian hujan, tanggal 11 Desember dengan hujan sebesar 44,97 $\mathrm{mm}$ menghasilkan tebal limpasan tertinggi. Sub DAS dengan limpasan tertinggi hingga terendah berturut-turut sebagai berikut: sub DAS Sumitro, sub DAS Serang Hilir, sub DAS Sidatan, sub DAS Sekiyep, sub DAS Nagung dan sub DAS http://jurnal.ugm.ac.id/mgi | 188 
Ngrancah. Besarnya limpasan total per sub DAS disajikan pada Tabel 3 .

Setelah diketahui kondisi total limpasan per sub DAS, kemudian disusun skenario optimalisasi tutupan lahan. Skenario tutupan lahan disusun dengan cara uji coba, mengubah cara pengolahan lahan dan tutupan lahan eksisting. Uji coba ini dilakukan pada setiap satuan lahan yang ada di setiap sub DAS hingga memperoleh limpasan paling rendah dengan nisbah antara tebal limpasan dan curah hujan (koefisien limpasan) minimal 0,5. Besar limpasan hasil uji coba menggunakan skenario tutupan lahan ditunjukkan pada Tabel 4. Satuan lahan digunakan sebagai unit analisis, karena dalam satu satuan lahan memiliki karakteristik yang seragam sehingga memudahkan dalam analisis.

Sebaran nilai koefisien limpasan eksisting pada setiap satuan lahan yang ada di setiap sub DAS, ditunjukkan pada Gambar 3. Satuan lahan dengan koefisien limpasan $>0,5$ ditunjukkan dengan warna gradasi orange hingga merah. Ditemukan di sub DAS Sumitro, dan sebagian sub DAS Sekiyep, Nagung, Serang Hilir dan Sidatan. Koefisien limpasan $>0,5$ umumnya berada pada tutupan lahan tegalan, sawah tadah hujan, sawah irigasi, dan pemukiman. Setelah dilakukan uji coba skenario tutupan lahan, sebaran nilai koefisien limpasan berubah seperti yang ditunjukkan pada Gambar 4.

Tabel 3. Besar Limpasan Total Per Sub DAS

\begin{tabular}{clcc}
\hline No & Sub DAS & $\begin{array}{c}\text { Volume } \\
\text { Limpasan } \\
(\mathrm{mm})\end{array}$ & $\begin{array}{c}\text { Debit Limpasan } \\
\left(\mathrm{m}^{3} / \text { detik }\right)\end{array}$ \\
\hline 1 & Sumitro & 16,52 & 10,76 \\
2 & Serang Hilir & 16,84 & 7,83 \\
3 & Nagung & 12,98 & 7,13 \\
4 & Sidatan & 14,67 & 4,86 \\
5 & Sekiyep & 14,66 & 2,78 \\
6 & Ngrancah & 9,39 & 2,12 \\
\hline
\end{tabular}

Sumber: Olah Data (2015)

Tabel 4. Besar Limpasan (Skenario) Total Per Sub DAS

\begin{tabular}{clcc}
\hline No & Sub DAS & $\begin{array}{c}\text { Debit } \\
\text { Limpasan } \\
\left(\mathrm{m}^{3} / \text { detik }\right)\end{array}$ & $\begin{array}{c}\text { Debit } \\
\text { Limpasan } \\
\left(\mathrm{m}^{3} / \text { detik }\right)\end{array}$ \\
1 & Sumitro & 10,76 & 10,05 \\
2 & Serang Hilir & 7,83 & 7,53 \\
3 & Nagung & 7,13 & 7,02 \\
4 & Sidatan & 4,86 & 4,72 \\
5 & Sekiyep & 2,78 & 2,56 \\
6 & Ngrancah & 2,12 & 2,11 \\
\hline
\end{tabular}

Sumber: Olah Data (2015)

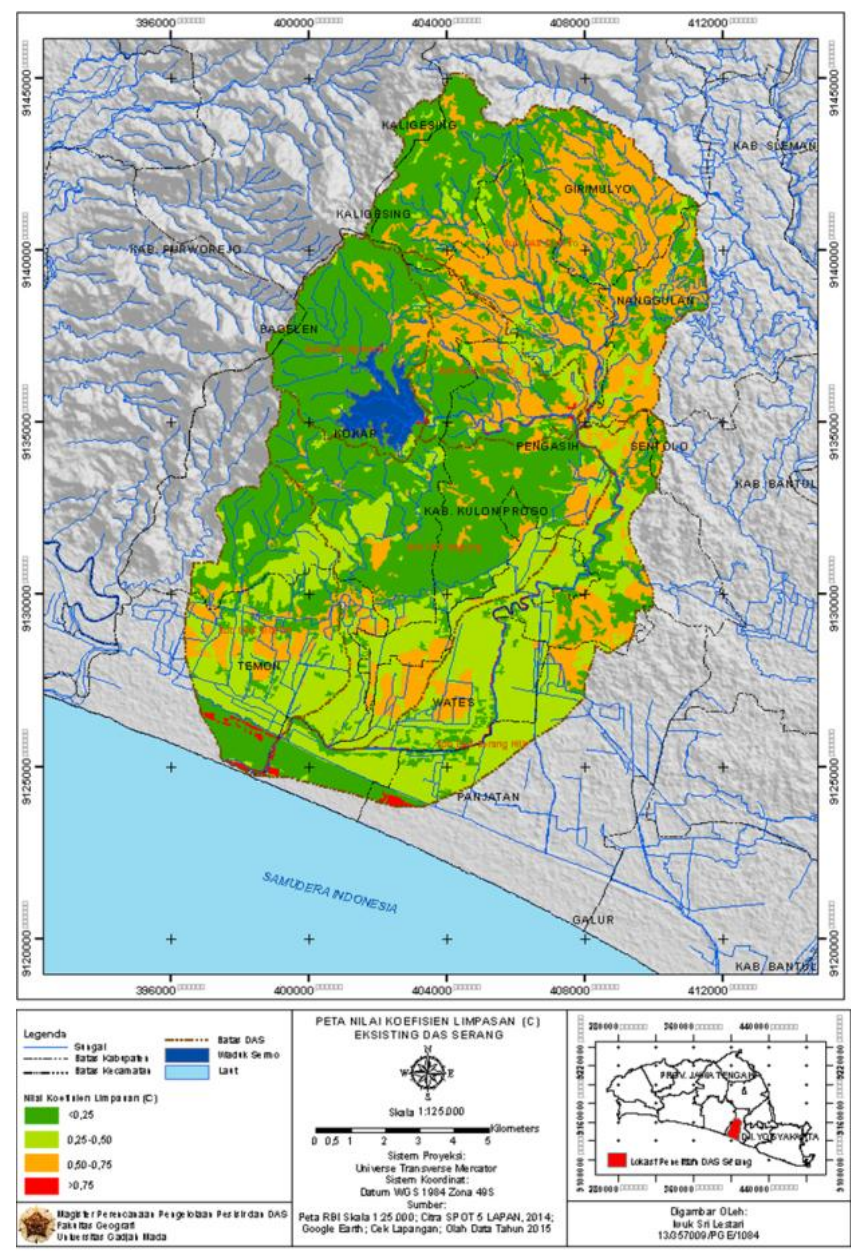

Gambar 4. Peta Sebaran Nilai Koefisien Limpasan Eksisting Pada Setiap Satuan Lahan di DAS Serang 
Tutupan lahan eksisting sebelum dilakukan uji coba skenario tutupan lahan ditunjukkan pada Gambar 5. Skenario tutupan lahan optimal agar limpasan yang dihasilkan rendah ditunjukkan pada Gambar 6.

\section{Optimalisasi Tutupan Lahan Ditinjau dari Aspek} Sosial, Ekonomi, Teknis dan Kebijakan

Optimalisasi tutupan lahan dari sisi sosial ekonomi, tetap memperhatikan jenis komoditas unggulan yang memiliki pasar jelas dan disukai masyarakat sebagai pemilik lahan. Optimalisasi dari sisi teknis konservasi yang utama adalah memperbaiki teras-teras di lahan pertanian dan perkebunan terutama pada lahan yang memiliki lereng III hingga V. Selain memperbaiki teras, penanaman sejajar kontur dan pemanfaatan sisa tanaman atau seresah sangat direkomendasi, sebab sisa tanaman atau seresah tersebut membantu mengurangi laju dan besarnya limpasan.

Optimalisasi dari sisi kebijakan, telah didukung dengan adanya Perda Kabupaten Kulonprogo nomor 1 Tahun 2012 tentang Rencana Tata Ruang Wilayah Kabupaten Kulonprogo Tahun 2012-2032 telah menjamin tentang Pola Ruang wilayah yang terdiri atas dua kawasan yaitu kawasan lindung dan budidaya Peraturan Pemerintah nomor 37 tahun 2012 tentang Pengelolaan DAS serta Peraturan Bupati Kulonprogo nomor 53 tahun 2013 tentang Rencana Pengelolaan DAS Terpadu DAS Serang.

\section{Strategi Pengelolaan DAS}

Limpasan di setiap sub DAS dapat diturunkan dengan:

a. Memperbaiki teras terutama pada lahan-lahan yang miring dengan batu-batu; tanaman penguat teras seperti kaliandra atau leresede; tanaman tahunan seperti jati lokal, mahoni atau albasiah.

b. Memperbaiki jalur penanaman (sejajar kontur untuk lahan miring).

c. Memanfaatkan sisa tanaman atau seresah untuk menghambat laju limpasan.

d. Memanfaatkan lahan kosong /semak menjadi kebun atau hutan-kombinasi rumput (kebun buah dan pohon);

e. Menambah jumlah tegakan pohon sebaiknya mempertimbangkan jenis-jenis pohon yang diminati masyarakat seperti jati (gmelina), sengon, kelapa, mahoni, albasiah, manggis dan petai.

f. Memanfaatkan lahan bawah tegakan untuk budidaya empon-empon atau rami. Selain bernilai ekonomis juga baik secara konservasi (melindungi tanah dari erosi).

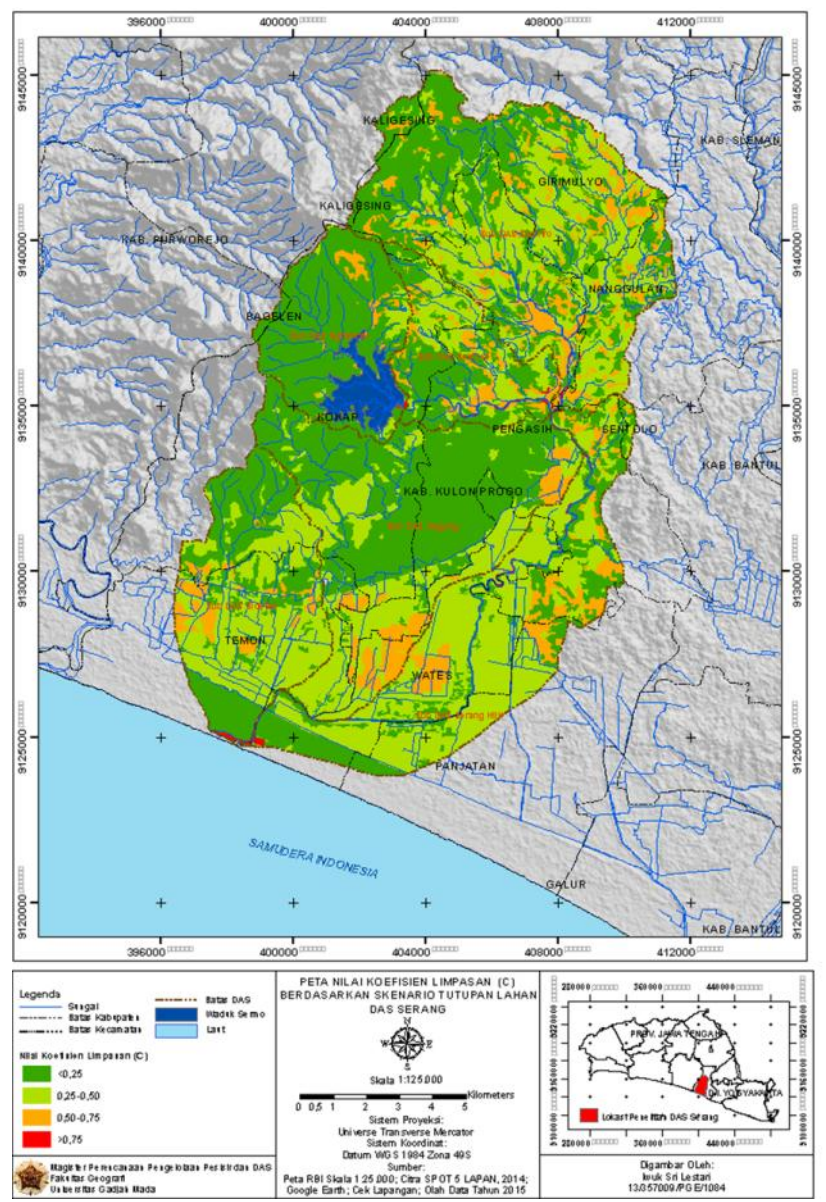

Gambar 5. Peta Sebaran Nilai Koefisien Limpasan Berdasarkan Skenario Tutupan Lahan di Setiap Satuan Lahan DAS Serang 


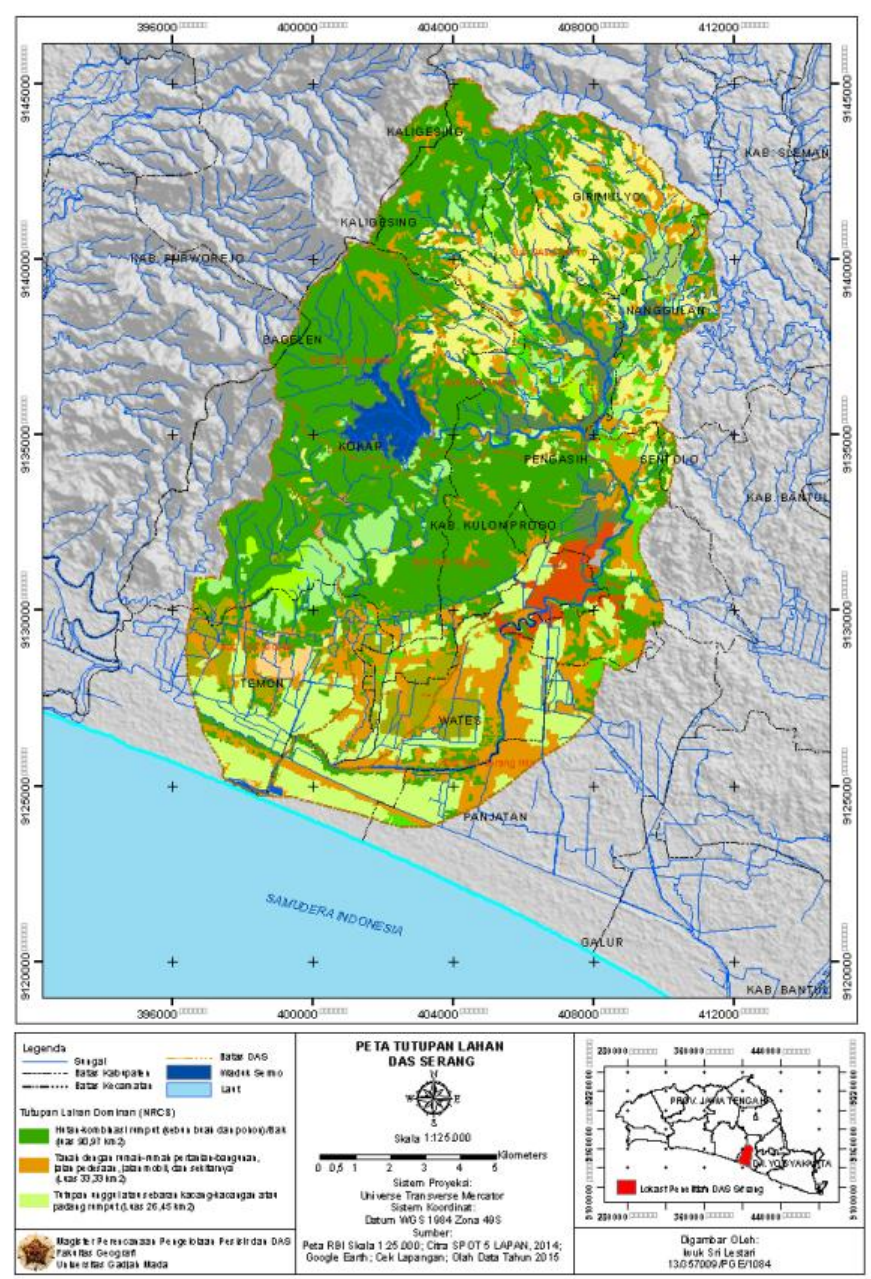

Gambar 6. Peta Tutupan Lahan DAS Serang

\section{KESIMPULAN}

1. Nilai CN dominan di DAS Serang adalah 58 (pada kondisi ARC II) berupa hutan-kombinasi rumput (kebun buah dan pohon) dengan kondisi baik pada kelompok tanah B. Nilai CN dominan kedua berupa tegalan dengan tutupan unggul atau sebaran kacang-kacangan atau padang rumput pada kelompok tanah $\mathrm{C}$ dengan penanaman jalur lurus dengan CN sebesar 81 (pada kondisi ARC II). Semakin tinggi nilai $\mathrm{CN}$, maka tebal limpasan semakin besar. Tegalan dengan nilai CN 81 memiliki tebal limpasan yang lebih besar dibanding kebun dengan nilai CN 58.

2. Uji coba dengan hujan wilayah masing-masing sub DAS menunjukkan pada kondisi ARC dan nilai CN/CN-Lereng yang sama, semakin tinggi curah hujan semakin besar tebal limpasan yang dihasilkan; Semakin tinggi ARC dan CN/CN-
Lereng, dengan hujan yang makin tinggi, tebal limpasan yang dhasilkan juga semakin tinggi; Tebal limpasan akan tetap tinggi pada kondisi ARC dan $\mathrm{CN} / \mathrm{CN}$-Lereng yang lebih tinggi, meskipun hujan yang jatuh lebih rendah. Uji coba dengan hujan wilayah seluruh DAS Serang menunjukkan pada hujan dan ARC yang sama, makin tinggi nilai CN/CN-Lereng, semakin besar tebal limpasan; pada kondisi ARC yang sama, dengan hujan dan nilai $\mathrm{CN} / \mathrm{CN}$-Lereng yang makin tinggi, menghasilkan tebal limpasan yang semakin tinggi.

3. Hasil estimasi tebal limpasan menggunakan nilai $\mathrm{CN}$ maupun CN-Lereng menunjukkan bahwa sub DAS dengan tebal limpasan tertinggi adalah sub DAS Sumitro dan Serang Hilir. Skenario optimalisasi tutupan lahan dilakukan dengan mengubah cara pengolahan lahan dan mengubah tutupan lahan eksisting. 


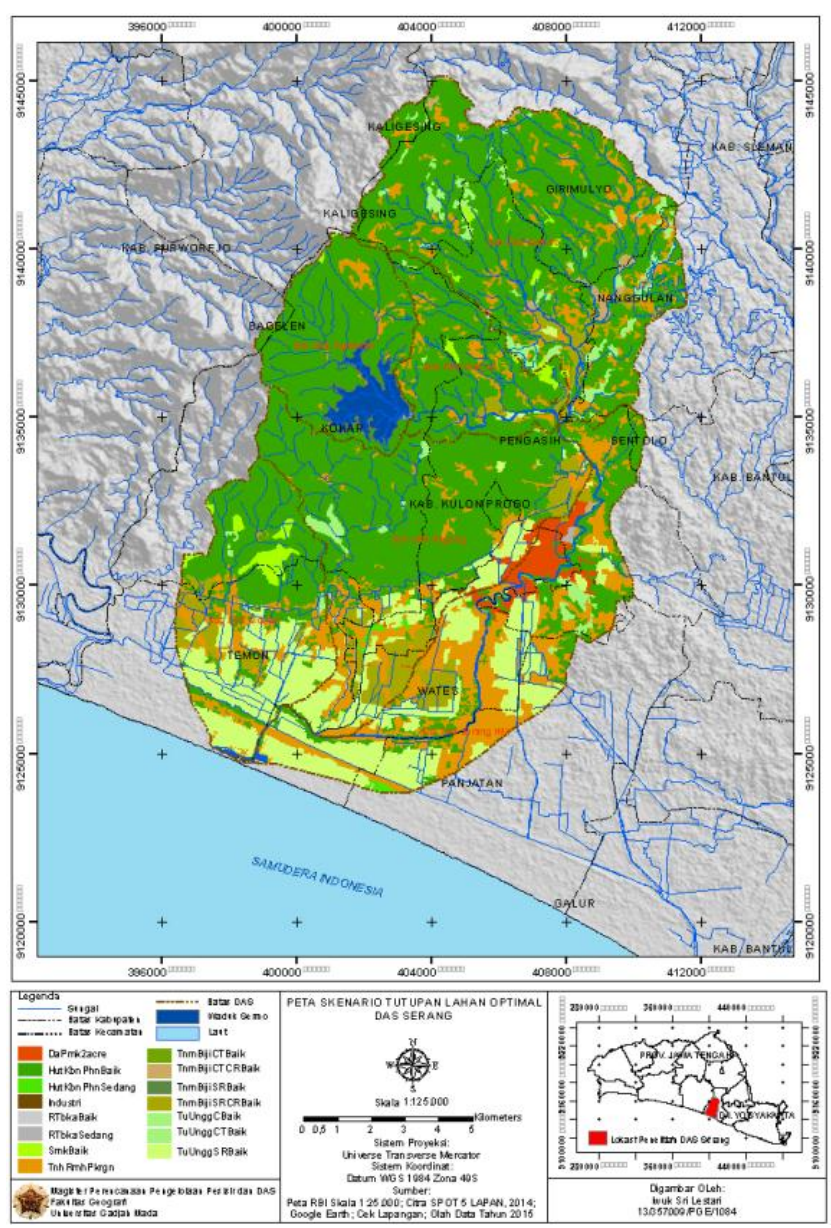

Gambar 7. Peta Sebaran Skenario Tutupan Lahan Optimal DAS Serang

\section{DAFTAR PUSTAKA}

Asdak, C. (2002). Hidrologi dan Pengelolaan Daerah Aliran Sungai. Yogyakarta: Universitas Gadjah Mada

Gunawan, T. (1991). Penerapan Teknik Penginderaan Jauh Untuk Menduga Debit Puncak Menggunakan Karakteristik Lingkungan Fisik DAS (Studi Kasus Di Daerah Aliran Sungai Bengawan Solo Hulu Jawa Tengah). Disertasi. Institut Pertanian Bogor

Natural Resources Conservation Service. (2004). Part 630 Hydrology National Engineering Handbook: Estimation of Direct Runoff from Storm Rainfall USA: USDA, Chapter 10.

Natural Resources Conservation Service. (2009). Part 630 Hydrology National Engineering Handbook: Hydrologic Soil Groups, USA: USDA, Chapter 7.

Neitsch, S.L., Arnold, J.G., Kiniry, R., Williams, J.R. (2011). "Soil and Water Assessment Tool
Theoretical Documentation Version 2009", Texas Water Resources Institute Technical Report No.406, Texas A and M University System.

Ponce, V.M., Hawkins, R.H. (1996). "Runoff Curve Number: Has It Reached Maturity?", Journal of Hidrologic Engineering. 1, 11-19.

Sudarmadji, Hadi, P., Widyastuti, M. (2014). Pengelolaan Sumberdaya Air Terpadu. Yogyakarta: Gadjah Mada University Press.

Peraturan:

Keputusan Menteri Kehutanan Nomor 328/MenhutII/2009 tentang Penetapan Urutan DAS Prioritas.

Perturan Direktur Jenderal Rehabilitasi Lahan dan Perhutanan Sosial Nomor P.001/V-DAS/2007 tanggal 30 Januari 2007 tentang Pedoman Pemantauan Tata Air Daerah Aliran Sungai Dengan Pendekatan Model Hidrologi. 


\section{LAMPIRAN}

Lampiran 1 Curve Number untuk Tutupan Lahan Perkotaan1)

\begin{tabular}{|c|c|c|c|c|c|}
\hline \multicolumn{2}{|l|}{ Penjelasan Tutupan Lahan } & \multicolumn{4}{|c|}{$\begin{array}{l}\text { Curve Number untuk Kelompok Hidrologi } \\
\text { Tanah }\end{array}$} \\
\hline Tipe Tutupan dan Kondisi hidrologi & Rata-Rata Area Kedap air ${ }^{2)}$ & $\mathrm{A}$ & $\mathrm{B}$ & $\mathrm{C}$ & $\mathrm{D}$ \\
\hline \multicolumn{6}{|l|}{$\begin{array}{l}\text { Daerah Perkotaan yang sepenuhnya dikembangkan } \\
\text { (pembuaan vegetasi) }\end{array}$} \\
\hline \multicolumn{6}{|l|}{$\begin{array}{l}\text { Ruang terbuka (rumput, taman, lapangan golf, } \\
\text { pemakaman, dll) })^{3)} \text { : }\end{array}$} \\
\hline Kondisi buruk (rumput $<50 \%$ ) & & 68 & 79 & 86 & 89 \\
\hline Kondisi sedang (rumput 50\%-75\%) & & 49 & 69 & 79 & 84 \\
\hline Kondisi baik (>75\%) & & 39 & 61 & 74 & 80 \\
\hline \multicolumn{6}{|l|}{ Area Kedap Air: } \\
\hline Parkir beraspal, atap, jalan mobil, dll & & 98 & 98 & 98 & 98 \\
\hline \multicolumn{6}{|l|}{ Jalan: } \\
\hline Beraspal, berbatu, selokan & & 98 & 98 & 98 & 98 \\
\hline Beraspal, selokan terbuka & & 83 & 89 & 92 & 93 \\
\hline Kerikil & & 76 & 85 & 89 & 91 \\
\hline Tanah & & 72 & 82 & 87 & 89 \\
\hline \multicolumn{6}{|l|}{ Daerah perkotaan: } \\
\hline Komersial dan bisnis & 85 & 89 & 92 & 94 & 95 \\
\hline Industri & 72 & 81 & 88 & 91 & 93 \\
\hline \multicolumn{6}{|l|}{ Daerah pemukiman yang luas } \\
\hline $1 / 8$ acre atau kurang & 65 & 77 & 85 & 90 & 92 \\
\hline $1 / 4$ acre & 38 & 61 & 75 & 83 & 87 \\
\hline $1 / 3$ acre & 30 & 57 & 72 & 81 & 86 \\
\hline $1 / 2$ acre & 25 & 54 & 70 & 80 & 85 \\
\hline 1 acre (0.405 ha) & 20 & 51 & 68 & 79 & 84 \\
\hline 2 acres & 12 & 46 & 65 & 77 & 82 \\
\hline \multicolumn{6}{|l|}{ Area perkotaan yang sedang berkembang } \\
\hline $\begin{array}{l}\text { Area baru (tidak ada vegetasi, hanya area yang tidak } \\
\text { kedap air) }\end{array}$ & & 77 & 86 & 91 & 94 \\
\hline \multicolumn{6}{|l|}{$\begin{array}{l}\text { Lahan Bero (nilai } \mathrm{CN} \text { ditentukan dengan tipe } \\
\text { tutupan untuk lahan pertanian lain/lihat tabel) }\end{array}$} \\
\hline \multicolumn{6}{|l|}{ 1) Kondisi limpasan rata-rata dan $\mathrm{Ia}=0.2 \mathrm{~S}$} \\
\hline \multicolumn{6}{|c|}{$\begin{array}{l}\text { 2) Rata-rata persentase area kedap air digunakan untuk mengembangkan nilai komposit CN dengan asumsi area kedap air } \\
\text { terhubung langung dengan sistem drainase. area kedap air memiliki CN 98. Area yang tidak kedap air dianggap setara dengan } \\
\text { ruang terbuka dengan kondisi hidrologi baik. Nilai CN dari kombinasi kondisi yang lain dihitung menggunakan persamaan } 3 \\
\text { dan } 4 \text {. }\end{array}$} \\
\hline \multicolumn{6}{|c|}{$\begin{array}{l}\text { 3) } \mathrm{CN} \text { yang ditampilkan adalah setara dengan padang rumput. CN komposit dihitung untuk kombinasi lain dari jenis tutupan pada } \\
\text { ruang terbuka. }\end{array}$} \\
\hline \multicolumn{6}{|l|}{$\begin{array}{l}\text { 4) CN komposit dihitung dengan menggunakan per } \\
\text { air) begitu pula untuk daerah yang tidak kedap air }\end{array}$} \\
\hline
\end{tabular}

Sumber: NRCS, 2004 
Lampiran 2 Curve Number untuk Lahan Pertanian1)

\begin{tabular}{|c|c|c|c|c|c|c|}
\hline \multicolumn{3}{|c|}{ Penjelasan Tutupan Lahan } & \multicolumn{4}{|c|}{$\begin{array}{c}\text { Curve Number untuk } \\
\text { Kelompok Hidrologi Tanah }\end{array}$} \\
\hline Tipe Tutupan & Pengolahan $^{2)}$ & Kondisi Hidrologi ${ }^{3)}$ & $\mathrm{A}$ & $\mathrm{B}$ & $\mathrm{C}$ & $\mathrm{D}$ \\
\hline \multirow{3}{*}{ Kosong/Belum ditanami } & Tanah gundul & 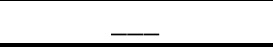 & 77 & 86 & 91 & 94 \\
\hline & Tutupan Sisa Tanaman (Crop Residu & Buruk & 76 & 85 & 90 & 93 \\
\hline & Cover/CR) & Baik & 74 & 83 & 88 & 90 \\
\hline \multirow[t]{12}{*}{ Jalur Tanaman } & Jalur Lurus (Straight Row/SR) & Buruk & 72 & 81 & 88 & 91 \\
\hline & & Baik & 67 & 78 & 85 & 89 \\
\hline & $\mathrm{SR}+\mathrm{CR}$ & Buruk & 71 & 80 & 87 & 90 \\
\hline & & Baik & 64 & 75 & 82 & 85 \\
\hline & Kontur (C) & Buruk & 70 & 79 & 84 & 88 \\
\hline & & Baik & 65 & 75 & 82 & 86 \\
\hline & $\mathrm{C}+\mathrm{CR}$ & Buruk & 69 & 78 & 83 & 87 \\
\hline & & Baik & 64 & 74 & 81 & 85 \\
\hline & Kontur dan Teras (C \& T) & Buruk & 66 & 74 & 80 & 82 \\
\hline & & Baik & 62 & 71 & 78 & 81 \\
\hline & $\mathrm{C} \& \mathrm{~T}+\mathrm{CR}$ & Buruk & 65 & 73 & 79 & 81 \\
\hline & & Baik & 61 & 70 & 77 & 80 \\
\hline \multirow[t]{12}{*}{ Tanaman Biji-bijian (small grain) } & Jalur Lurus (SR) & Poor & 65 & 76 & 84 & 88 \\
\hline & & Good & 63 & 75 & 83 & 87 \\
\hline & $\mathrm{SR}+\mathrm{CR}$ & Buruk & 64 & 75 & 83 & 86 \\
\hline & & Baik & 60 & 72 & 80 & 84 \\
\hline & Kontur (C) & Buruk & 63 & 74 & 82 & 85 \\
\hline & & Baik & 61 & 73 & 81 & 84 \\
\hline & $\mathrm{C}+\mathrm{CR}$ & Buruk & 62 & 73 & 81 & 84 \\
\hline & & Baik & 60 & 72 & 80 & 83 \\
\hline & Kontur dan Teras (C \& T) & Buruk & 61 & 72 & 79 & 82 \\
\hline & & Baik & 59 & 70 & 78 & 81 \\
\hline & $\mathrm{C} \& \mathrm{~T}+\mathrm{CR}$ & Buruk & 60 & 71 & 78 & 81 \\
\hline & & Baik & 58 & 69 & 77 & 80 \\
\hline \multirow{6}{*}{$\begin{array}{l}\text { Tutupan unggul atau sebaran } \\
\text { kacang-kacangan atau padang } \\
\text { rumput }\end{array}$} & SR & Buruk & 66 & 77 & 85 & 89 \\
\hline & & Baik & 58 & 72 & 81 & 85 \\
\hline & $\mathrm{C}$ & Buruk & 64 & 75 & 83 & 85 \\
\hline & & Baik & 55 & 69 & 78 & 83 \\
\hline & $\mathrm{C} \& \mathrm{~T}$ & Buruk & 63 & 73 & 80 & 83 \\
\hline & & Baik & 51 & 67 & 76 & 80 \\
\hline \multirow{4}{*}{$\begin{array}{l}\text { Padang rumput dan lahan } \\
\text { penggembalaan, range-yang } \\
\text { digunakan untuk pakan ternak } \\
\text { Padang rumput- untuk rumput. } \\
\text { dilindungi dari penggembalaan } \\
\text { dan umumnya disiangi untuk } \\
\text { membuat rumpt kering }\end{array}$} & & Buruk & 68 & 79 & 86 & 89 \\
\hline & & Sedang & 49 & 69 & 79 & 84 \\
\hline & & Baik & 39 & 61 & 74 & 80 \\
\hline & & Baik & 30 & 58 & 71 & 78 \\
\hline \multirow{3}{*}{$\begin{array}{l}\text { Semak-campuran antara semak, } \\
\text { gulma, rumput dengan dominasi } \\
\text { semak-semak }\end{array}$} & & Buruk & 48 & 67 & 77 & 83 \\
\hline & & Sedang & 35 & 56 & 70 & 77 \\
\hline & & Baik & $30^{6)}$ & 48 & 65 & 73 \\
\hline \multirow{3}{*}{$\begin{array}{l}\text { Hutan-kombinasi rumput (kebun } \\
\text { buah dan pohon) })^{7)}\end{array}$} & & Buruk & 57 & 73 & 82 & 86 \\
\hline & & Sedang & 43 & 65 & 76 & 82 \\
\hline & & Baik & 32 & 58 & 72 & 79 \\
\hline \multirow[t]{3}{*}{ Hutan $^{8)}$} & & Buruk & 45 & 66 & 77 & 83 \\
\hline & & Sedang & 36 & 60 & 73 & 79 \\
\hline & & Baik & $30^{4)}$ & 55 & 70 & 77 \\
\hline
\end{tabular}


Lanjutan Lampiran 2.

\begin{tabular}{|c|c|c|c|c|c|c|}
\hline \multicolumn{3}{|c|}{ Penjelasan Tutupan Lahan } & \multicolumn{4}{|c|}{$\begin{array}{c}\text { Curve Number untuk } \\
\text { Kelompok Hidrologi Tanah }\end{array}$} \\
\hline Tipe Tutupan & Pengolahan $^{2)}$ & Kondisi Hidrologi3) & $\mathrm{A}$ & $\mathrm{B}$ & $\mathrm{C}$ & $\mathrm{D}$ \\
\hline $\begin{array}{l}\text { Tanah dengan rumah-rumah } \\
\text { pertanian-bangunan, jalan } \\
\text { pedesaan, jalan mobil, dan } \\
\text { sekitarnya }\end{array}$ & & - & 59 & 74 & 82 & 86 \\
\hline $\begin{array}{l}\text { Jalan: } \\
\text { Tanah } \\
\text { Kerikil }\end{array}$ & & - & $\begin{array}{l}72 \\
76\end{array}$ & $\begin{array}{l}82 \\
85\end{array}$ & $\begin{array}{l}87 \\
89\end{array}$ & $\begin{array}{l}89 \\
91\end{array}$ \\
\hline $\begin{array}{l}\text { 1) Kondisi limpasan rata-rata } \\
\text { 2) Penutupan sisa tanaman ber } \\
\text { 3) Kondisi hidrolik didasarkan } \\
\text { dan kanopi daerah vegetatif; (b } \\
\text { residu penutup pada permuka } \\
\text { Buruk: faktor yang menguran } \\
\text { Baik : faktor yang rata-rata m } \\
\text { 4) Buruk : <50\% terdapat pen } \\
\text { Sedang: } 50 \text { sampai } 75 \% \text { terd } \\
\text { Baik : }>75 \% \text { terdapat pen } \\
\text { 5) Buruk : }<50 \% \text { terdapat per } \\
\text { Sedang : } 50 \text { sampai } 75 \% \text { ter } \\
\text { Baik : }>75 \% \text { terdapat per } \\
\text { 6) CN aktual kurang dari } 30 \text {; } \\
\text { 7) CN yang ditunjukkan di ata } \\
\text { Kombinasi kondisi lainnya dap } \\
\text { 8) Buruk : sampah hutan. poh } \\
\text { Sedang : hutan yang berump } \\
\text { Baik : hutan yang dilindu }\end{array}$ & $\begin{array}{l}\text { sidu setidaknya } \\
\text { r kombinasi ya } \\
\text { sepanjang tahu } \\
\text { 0\%); dan (e) tin } \\
\text { nderung menin } \\
\text { mbuat lebih bai } \\
\text { rumput tanpa } \\
\text { h dan tidak ban } \\
\text { dikit atau berun } \\
\text { ah }\end{array}$ & $\begin{array}{l}\text { nukaan sepanjang tah } \\
\text { aruhi infiltrasi dan lim } \\
\text { rumput atau serupa } \mathrm{k} \\
\text { in permukaan. } \\
\text { asan. } \\
\text { filtrasinya dan menur }\end{array}$ & an. te & $\begin{array}{l}\text { asuk } \\
\text { gan. }\end{array}$ & kepa & \\
\hline
\end{tabular}

Sumber: NRCS, 2004 